\title{
Article \\ Expression of Recombinant Human Octamer-Binding Transcription Factor 4 in Rice Suspension Cells
}

\author{
Li-Fen Huang ${ }^{1, *}$, Desyanti Saulina Sinaga ${ }^{1} \oplus$, Chia-Chun Tan ${ }^{1,2}$, Shu-Ju Micky Hsieh ${ }^{2}$ and Chi-Hung Huang ${ }^{2}$ \\ 1 Graduate School of Biotechnology and Bioengineering, Yuan Ze University, 135 Yuan-Tung Road, Zhongli, \\ Taoyuan County 320, Taiwan; desyanti@g.ncu.edu.tw (D.S.S.); smallbu1023@yahoo.com.tw (C.-C.T.) \\ 2 Taiwan Advance Bio-Pharmaceutical Inc., 12F, No. 25, Ln. 169, Kangning St, Xizhi Dist., \\ New Taipei City 221, Taiwan; mickyhsieh@biotest.com.tw (S.-J.M.H.); chh@biotest.com.tw (C.-H.H.) \\ * Correspondence: Hlf326@saturn.yzu.edu.tw; Tel.: +886-3-463-8800 (ext. 2189); Fax: +886-3-433-4667
}

Citation: Huang, L.-F.; Sinaga, D.S.; Tan, C.-C.; Hsieh, S.-J.M.; Huang, C.-H. Expression of Recombinant Human Octamer-Binding Transcription Factor 4 in Rice Suspension Cells. Int. J. Mol. Sci. 2021, 22, 1409. https://doi.org/ 10.3390/ijms22031409

Received: 21 December 2020

Accepted: 28 January 2021

Published: 30 January 2021

Publisher's Note: MDPI stays neutral with regard to jurisdictional claims in published maps and institutional affiliations.

Copyright: (c) 2021 by the authors. Licensee MDPI, Basel, Switzerland. This article is an open access article distributed under the terms and conditions of the Creative Commons Attribution (CC BY) license (https:/ / creativecommons.org/licenses/by/ $4.0 /)$.

\begin{abstract}
The rice cell suspension culture system is a good way to produce recombinant human proteins, owing to its high biosafety and low production cost. Human Octamer-binding Transcription Factor 4 (Oct4) is a fundamental transcription factor responsible for maintaining human pluripotent embryonic stem cells. Recombinant Oct4 protein has been used to induce pluripotent stem cells. In this study, recombinant Oct 4 proteins are produced via a sugar starvation-inducible $\alpha A m y 3 / R A m y 3 D$ promoter-signal peptide-based rice recombinant protein expression system. Oct4 mRNAs accumulate in the transgenic rice suspension cells under sugar starvation. The Oct4 recombinant protein is detected in the transgenic rice suspension cells, and its highest yield is approximately $0.41 \%$ of total cellular soluble proteins after one day of sugar starvation. The rice cell-synthesized recombinant human Oct4 protein show DNA-binding activity in vitro, which implies that the protein structure is correct for enabling specific binding to the target DNA motif.
\end{abstract}

Keywords: $\alpha A m y 3$ promoter; recombinant human embryonic transcription factor; human Oct4; rice cell suspension culture system

\section{Introduction}

There has been a recent surge in applications of human-induced pluripotent stem cells (iPSCs) in therapeutics research, such as in drug screening, disease modeling, and gene identification, together with the potential for patient-specific tissue replacement [1-3]. Human Octamer-binding Transcription Factor 4 (Oct4) is a homeodomain transcription factor that belongs to the POU (Pit-Oct-Unc) family and acts as a pioneer factor to initiate reprogramming of fibroblasts into iPSCs [4]. Oct4 contains a DNA-binding domain and activates target genes by recognizing the consensus sequence ATGCAAAT in promoter or enhancer regions. Oct4 is mainly expressed in unfertilized oocytes, zygotes, early embryos, and primordial germ cells $[5,6]$, and functions together with SOX2 and NANOG to regulate self-renewal and pluripotency of embryonic stem cells [7]. In addition, in vitro cell reprogramming studies indicate that Oct4 is expressed abundantly in embryonal carcinoma cells and embryonic stem cells [8,9]. Ectopic expression of Oct4 and other reprogramming factors can reprogram somatic cells into iPSCs [10]. The virus-mediated gene transfer process is a common method to deliver these reprogramming factor's genes. However, the approach may result in unwanted genomic mutations, residual expression, and reactivation of transgenes [11]. Therefore, several transgene-free approaches were developed to avoid or eliminate the integration of transgenes in the reprogrammed cells [12-16]. Direct transduction of reprogramming factor proteins is one of the transgene-free approaches, which adds recombinant reprogramming factor proteins, such as the Oct4, to the culture medium of host cells to induce reprogramming [17].

To derive the recombinant Oct4 for iPSCs formation, several protein expression platforms have expressed recombinant human Oct4, such as mammalian cells [18], in- 
sect cells [19], the yeast Pichia pastoris [20], and Escherichia coli [21], but some problems have been encountered. In mammalian expression systems, recombinant Oct4 proteins are limited by low yields, cumbersome manipulations, and high culture costs [18]. In baculovirusinfected Sf9 insect cells, the secreted recombinant Oct4 proteins were detectable only in cell debris and not in the cell culture medium [19]. Production of Oct4 in P. pastoris is strongly induced by methanol [20], but there are concerns about the toxic and inflammatory nature of methanol. In E. coli, recombinant Oct4 proteins are aggregated at inclusion bodies, hence additional denaturation and recovery steps are required during protein purification [21].

A plant cell system is a promising recombinant protein production platform owing to the capacity for post-translational modification, as well as the low production cost. In addition, a plant cell system faces little or no risk of human pathogen contamination, and therefore, offers a high level of biosafety compared with current commercial mammalian and microbial host cells [22]. Rice is a low-allergen staple food and a model research plant. With advantages, such as well-developed genetic transformation technology [23,24], short cell-doubling time, and straightforward downstream protein purification, a rice cell suspension culture system is recognized as an excellent host cell for recombinant protein production [25]. Several recombinant proteins, such as human serum albumin [26], cytokines [27-29], antibodies, and vaccines [30,31], have been produced successfully by a rice cell suspension culture system, which produces competitive yields of several recombinant proteins among several plant species [32].

The most widely applied transgenic rice cell suspension culture system is based on the rice $\alpha$-amylase promoter $\alpha A m y 3$ (also termed RAmy3D), which is a sugar starvationinducible promoter [33], and its signal peptide [34]. In the present study, we constructed and transformed the human Oct4 gene controlled by the $\alpha A m y 3$ promoter and its signal peptide into rice suspension cells [35]. Several independent transgenic suspension cell lines were obtained. Expression of Oct4 mRNAs and recombinant human Oct4 was monitored in these transgenic suspension cell lines in sugar-supplemented and sugar-starved media. In addition, the DNA-binding ability of the rice-derived recombinant human Oct4 protein was compared with that of commercial recombinant TAT-Oct4, an Oct4 fusion protein carrying the cell-penetrating the TAT domain from HIV.

\section{Results and Discussion}

\subsection{Generation of Transgenic Rice Cell Lines Harboring aAmy3p-SP-Oct4 Gene}

The sugar starvation-inducible $\alpha A m y 3$ promoter $(\alpha A m y 3 p)$ and its signal peptide $(\alpha A m y 3 \mathrm{SP})$ have been used successfully to express diverse recombinant proteins in rice suspension cells [25]. To produce the recombinant human Oct4 transcription factor in rice suspension cells, full-length Oct4 cDNA was inserted downstream of $\alpha$ Amy3p and $\alpha$ Amy3SP (Figure 1) in a Gateway-compatible T-DNA destination vector. The T-DNA expression cassette was transformed into rice cells via an Agrobacterium-mediated plant transformation system. Several stable transgenic rice calli were obtained (Supplemental Figure S1A). Four independent transgenic rice calli that produced high levels of Oct4 mRNA, namely, Oct4-a1, Oct4-5, Oct4-6, and Oct4-8 (Supplemental Figure S1B), were selected and used to establish suspension cell lines.

\subsection{Recombinant Human Oct4 Proteins Were Produced by Transgenic Rice Suspension Cell Lines}

To examine Oct4 expression in the four selected rice suspension cell lines, $3 \%(v / v)$ of each sample of rice cells was incubated in sucrose-containing culture medium for three days before being transferred to sucrose-free medium for two days. To analyze expression levels of Oct4 mRNA and the recombinant human Oct4 (rhOct4) protein, quantitative real-time PCR (qRT-PCR) and immunoblotting analysis were performed, respectively. The Oct4 mRNAs were detected in the four suspension cell lines, and Oct4-a1 exhibited the highest level of Oct4 mRNA among the cell lines (Figure 2A). The predicted $43 \mathrm{kDa}$ rhOct4 protein was detected in cellular soluble proteins of two suspension cell lines, Oct4-a1 and Oct4-6. 
Using monoclonal anti-Oct4 antibodies, the abundance of rhOct4 was higher in Oct4-a1 than Oct4-6 (Figure 2B). In addition, rhOct4 protein was not directly detectable in the sucrose-free culture-medium for all four suspension cell lines. To increase the concentration of rhOct 4 proteins in the cell-culture medium, $12 \%(v / v)$ of Oct4-a1 and Oct4-6 rice cells were incubated in sucrose-containing and sucrose-free media for two days. Ten-fold condensed cell-culture medium samples were prepared by freeze-drying. Then, the rhOct 4 protein was detected in $\mathrm{t}$ cell-culture media for the Oct4-a1 and Oct4-6 lines by immunoblotting analysis (Figure 2C). The Oct4 protein contains conserved amino acid residues for O-glycosylation [36], and rhOct4 is secreted by a default pathway from the endoplasmic reticulum and Golgi apparatus where glycans may be added to the rhOct4 protein. Thus, a molecular weight higher than $43 \mathrm{kDa}$ was observed for rhOct 4 in the sugar-free culture medium of the Oct4-a1 line (Figure 2C). In addition, a high quantity of a small rhOct4 fragment, around $25 \mathrm{kDa}$, was detected in the sugar-free culture medium (Figure 2C). Small protein fragments of rhOct4 were detected in the sugar-free culture medium for both the Oct4-a1 and Oct4-6 cell lines. Based on the Oct4 mRNA levels and intracellular rhOct4 protein levels in these transgenic lines, the results suggest that the secreted rhOct4 proteins might be degraded in the sugar-free cell-culture medium.

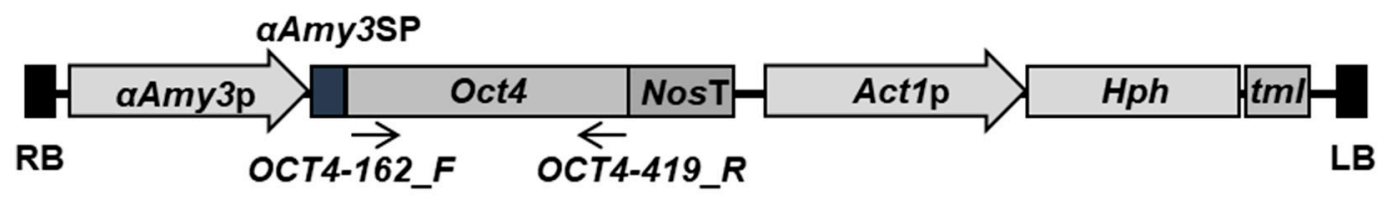

Figure 1. Schematic representation of the human Oct4 expression cassette in transgenic rice plants. The human Oct4 cDNA was inserted downstream of the $\alpha A m y 3$ promoter $(\alpha A m y 3 p)$-signal peptide $(\alpha A m y 3 S P)$ sequence. Expression of the hygromycin phosphotransferase resistance $(\mathrm{Hph})$ gene was driven by an actin promoter (Act1p), and the terminator of the Agrobacterium tml gene was used. RB, T-DNA right border; Nos T, Nopaline synthase terminator; LB, T-DNA left border. Two primers used to amplify the inserted Oct4 gene were designated OCT4-162_F and OCT4-419_R.

\subsection{The rhOct4 Protein Is Unstable in Sugar-Free Culture Medium}

A time-course in vitro assay of rhOct 4 protein stability in the culture medium was performed to assess whether rhOct4 protein is degraded. Crude protein extracts from Oct4-a1 cells sugar-starved for two days were incubated either with a cell-culture medium or with a medium for only 5 or $24 \mathrm{~h}$. Reaction mixtures were subjected to immunoblotting analysis with monoclonal anti-Oct4 antibodies. Similar abundances of rhOct4 protein were detected after $5 \mathrm{~h}$ incubation in the three reaction mixtures (Figure 3, Lanes 2-4). However, compared with medium-only, rhOct4 protein was only weakly detectable in the cell-culture medium after $24 \mathrm{~h}$ (Figure 3, Lane 5), whereas rhOct4 protein signals remained high when incubated in medium-only (Figure 3, Lanes 6 and 7). The average $\mathrm{pH}$ in a sugar-free cell-culture medium changed to 7.6 from the initial 5.8 during incubation for two days. To test whether the $\mathrm{pH}$ change affected rhOct4 protein stability, a sucrose-free Murashige and Skoog (MS) medium of pH 5.8 and 7.6 were used. The rhOct4 protein abundances were similar in the sugar-free MS medium under the two $\mathrm{pH}$ values (Figure 3, Lanes 6 and 7), implying that rhOct4 protein instability was not major affected by the increase of $\mathrm{pH}$ in a sugar-free cell-culture medium that may contain rice secretary proteases. Few recombinant biopharmaceutical proteins in a plant-based recombinant protein production system, such as monoclonal antibodies [37-39], have been reported in which protein fragments truncated via a proteolytic process were detected. Previous reports indicate that cysteine proteases exist in a sugar-free culture medium of rice suspension cells, and these proteases have negative impacts on the production of recombinant human granulocyte-macrophage colony-stimulating factor [40,41]. Unstable rhOct4 proteins in a sugar-free cell-culture medium might be attacked by particular proteases secreted from rice suspension cells into sugar-free medium. Our protease activity assay showed that approximately 60-70 and $150 \mathrm{kDa}$ proteases were detected in sugar-deficient rice cell 
cultured medium (Supplementary Figure S2). By using RNAseq and proteomic analyses, several secreted proteases were found in sugar-free culture medium. If the particular proteases degrade rhOct 4 protein, specific protease inhibitors can be applied to increase rhOct4 protein level in a sugar-free cell-culture medium.

(A) Oct4 mRNA

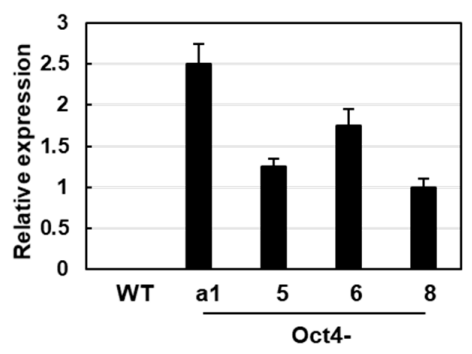

(B) Cellular proteins

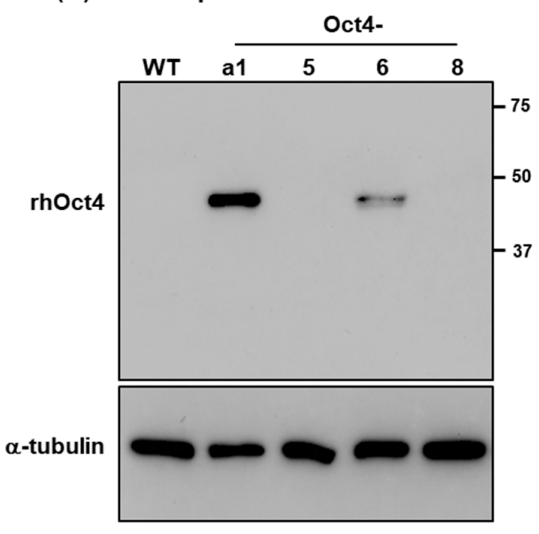

(C) Secreted proteins

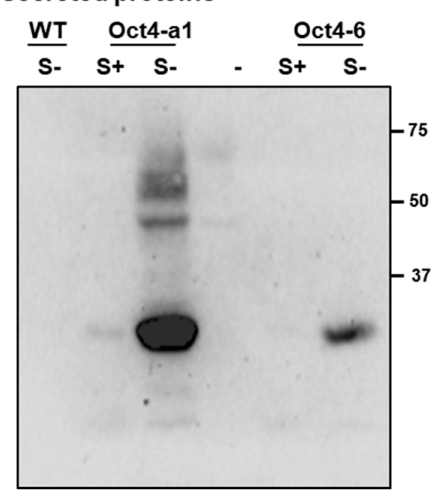

Figure 2. Establishment and characterization of Oct4 transgenic suspension cell lines. (A) Expression of Oct4 in rice suspension cells. Total RNA was isolated from sugar-starved cells cultured for two days and then analyzed by qRT-PCR using Oct4-specific primers. WT is the non-transformed wild-type line used as a negative control. Error bars indicate the standard deviation (SD) of triplicate experiments. Gene expression was relative to that of Oct4-8 cells, with $1=$ equivalence. (B) Suspension cells of the WT and four Oct4 transgenic lines (Oct4-a1, Oct4-5, Oct4-6, and Oct4-8) were cultured in a sugar-free MS medium for two days. Total soluble proteins were isolated to determine recombinant human Oct4 (rhOct4) abundance by western blot analysis with specific Oct 4 antibodies. $\alpha$-Tubulin was detected as the loading control. (C) WT, Oct4-a1, and Oct4-6 suspension cells were cultured in a sugar-free MS medium with $12 \%(\mathrm{v} / \mathrm{v})$ cell concentrations for two days. The culture media were collected and condensed 10-fold after freeze-drying. The media were used to determine rhOct4 abundance by western blot analysis with anti-Oct4 antibodies. 


\section{Cellular protein Oct4-a1}

Cultured-medium Oct4-a1

MS-S medium pH 5.8

MS-S medium pH 7.6

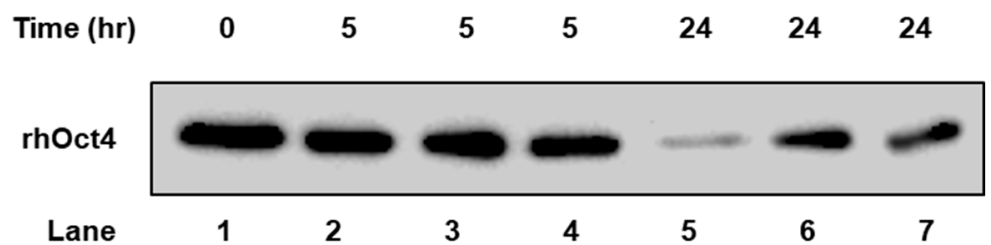

Figure 3. Analysis of rhOct4 protein stability in rice cell suspension culture medium. Cellular proteins extracted from Oct4-a1 suspension cells sugar-starved for two days were incubated with a cell-culture medium of Oct4-a1, fresh MS medium with pH 5.8, or fresh MS medium with pH 7.6 for 5 or $24 \mathrm{~h}$. The rhOct 4 abundance was determined by western blot analysis with human Oct 4 antibodies.

\subsection{The Highest Production of Oct4 Protein Was $0.41 \%$ of Total Soluble Proteins}

Although rhOct4 proteins were of low abundance in the suspension cell culture medium, the Oct4-a1 cell line produced a high abundance of cellular rhOct4 proteins. To determine the highest yield of cellular rhOct4 production in the Oct4-a1 suspension cell line, the Oct4-a1 cells were starved for various periods before being subjected to total mRNA and total protein extraction. The Oct4 mRNA levels were quantified by qRT-PCR. The abundance of Oct4 mRNA increased dramatically in cells cultured for 1 and 2 days under sugar starvation, and thereafter, gradually decreased from Day 3 to Day 4 (Figure $4 \mathrm{~A}$ ). The rhOct 4 abundance during sugar-starvation periods was detected by immunoblotting analysis, and relative quantification was performed with a Bio-Rad Gel Doc EZ Imaging system using $50 \mathrm{ng}$ purified TAT-Oct 4 fusion protein from recombinant $E$. coil as a standard. The highest rhOct4 production was detected on Day 1 after sugar starvation (Figure 4B). The yield of rhOct 4 was approximately $165 \mathrm{ng}$, which represents $0.41 \%$ of the total soluble proteins (Figure $4 \mathrm{C}$ ).

Recombinant Oct4 proteins were produced in mammalian cells [18], insect cells [19], yeast [20], and E. coli. [21]. Although some reports do evaluate their protein yields, various units were used. The yield from previous studies in insect cells and yeast showed that the recombinant Oct4 yield was $6.1 \mathrm{mg} / \mathrm{L}$ [19] and $210 \mathrm{mg} / \mathrm{L}$ [21], respectively. Our present study indicates that the yield of rhOct 4 was approximately $0.41 \%$ of the total soluble proteins. According to the protein levels in sugar-starved rice suspension cell, about $4534.9 \mu^{-1} \mathrm{~g}^{-1}$ cell [42], and $1 \mathrm{~L}$ of an initial cell density of $12 \%(v / v)$ cultured cells is roughly equivalent to $120 \mathrm{~g}$ of rice suspension cells, the recombinant Oct4 yield in rice cells was about $223 \mathrm{mg} / \mathrm{L}$, implying that the productivity is now in the same order of magnitude as yeast.

\subsection{Rice Cells Produce Biologically Active rhOct4}

Oct- 4 belongs to the POU family and contains a bipartite DNA-binding domain consisting of the POU-specific and POU homeo-domain. The biological activity of rhOct4 was determined by its intrinsic DNA-binding ability. The DNA-binding activity of various concentrations of rice cell-derived rhOct4 and of E. coli-derived recombinant TAT-Oct 4 was tested using the TransAM ${ }^{\circledR}$ Oct-4 Transcription Factor Assay Kit. No DNA-binding activity was detected in the non-transformed wild-type line (WT) extract that contained no rhOct4 (Figure 5). In contrast, DNA-binding activity increased significantly in the presence of rice cell-derived rhOct4 in a dose-dependent manner (Figure 5). Moreover, rhOct4 activity was similar to that of E. coli-derived recombinant TAT-Oct4 (Figure 5). These results indicate that the rhOct4 protein was biologically active. 


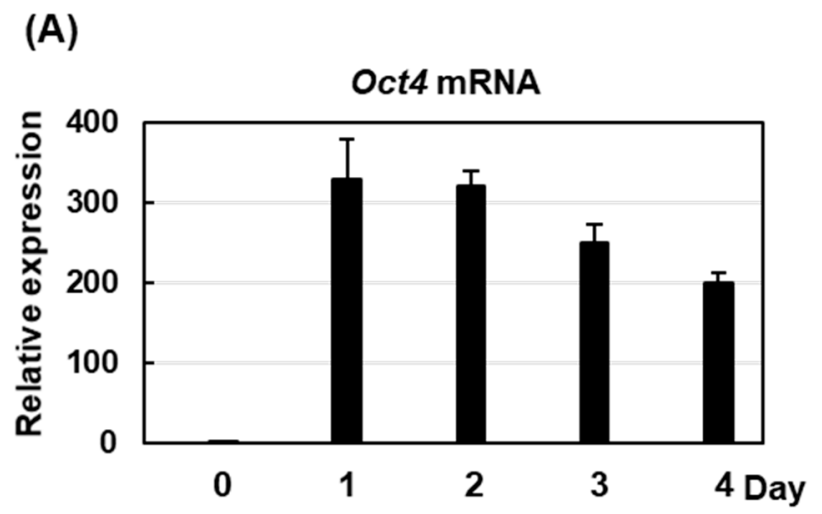

(B)
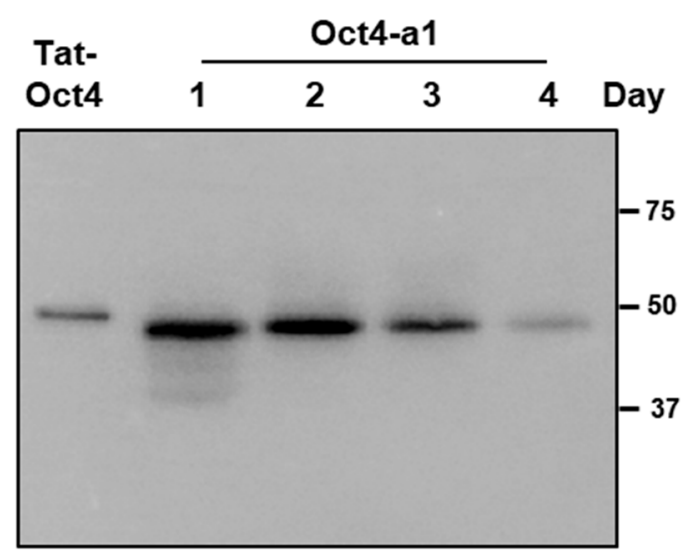

(C)

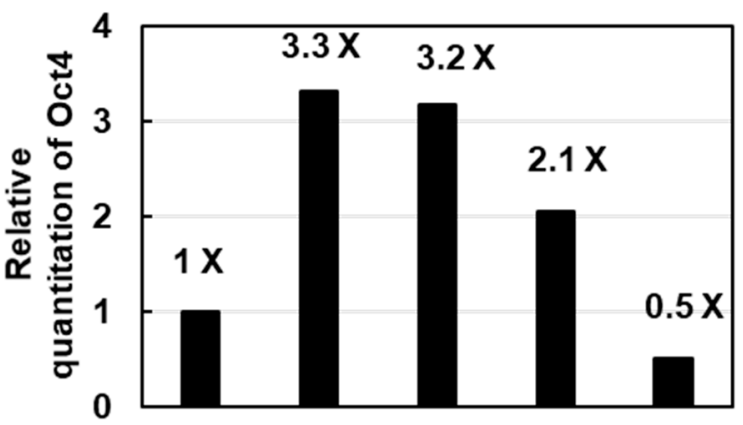

Figure 4. The production profile of rhOct4 in rice suspension cells. Three milliliters of Oct4-a1 suspension cells were cultured in $25 \mathrm{~mL}$ sugar-free MS for 1 to 4 days. Total RNA and total soluble proteins were isolated and subjected to qRT-PCR and western blot analysis. (A) Relative expression of Oct4 was determined with Oct4-specific primers. Error bars indicate the standard deviation (SD) of triplicate experiments. Gene expression was relative to that at Day 0 , with $1=$ equivalence. (B) Western blot analysis was performed using Oct4 antibodies. Equal quantities of total protein $(40 \mu \mathrm{g})$ per lane were loaded. Fifty grams of commercial TAT-Oct4 recombinant protein produced from E. coli was used as a positive control. (C) Relative quantification of rhOct4 protein yield in Oct4-a1 under various sugar-starvation durations was measured using a Bio-Rad Gel Doc EZ Imager system. The level of rhOct 4 was relative to that of Tat-Oct4, with $1=$ equivalence. 


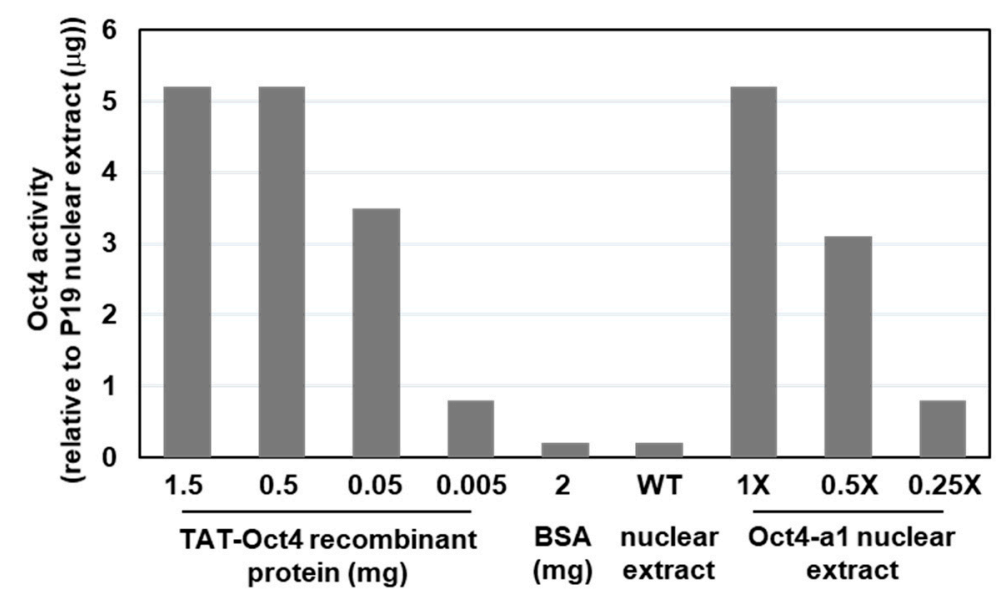

Figure 5. Analysis of the biological activity of rhOct4. The biological activity of rhOct4 was determined in cellular protein extract from Oct4-a1 suspension cells sugar-starved for one day. An oligonucleotide containing the Oct4 consensus binding site was incubated with three different dilutions of Oct4-a1 cellular protein extracts. Commercial TAT-Oct4 derived from E. coli cells was used as a reference standard, ranging from 0.005 to $1.5 \mathrm{mg}$. Two milligrams of bovine serum albumin (BSA) and wild-type rice nuclear extract (WT) were used as negative controls. The Oct4 DNA-binding activity was relative to the positive control (P19 nuclear extract).

\section{Materials and Methods}

\subsection{Plant Materials and Growth Conditions}

Seeds of rice (Oryza sativa L.), Tainung 67, were dehulled, sterilized with $2.4 \% \mathrm{HClO}_{2}$ containing Tween-20, agitated on a shaker for $30 \mathrm{~min}$, washed thoroughly with sterile water, and cultured on CIM-I agar medium [23] containing $3 \%$ sucrose at $28{ }^{\circ} \mathrm{C}$ in a growth chamber under continuous light to induce callus.

To establish the rice cell suspension culture, yellow healthy embryogenic calli were transferred to MS liquid medium [43] supplemented with $3 \%$ sucrose and $10 \mu \mathrm{M}$ dichlorophenoxyacetic acid (2,4-D) in a $125 \mathrm{~mL}$ flask. The cells were cultured at $28{ }^{\circ} \mathrm{C}$ on an orbital shaker at $110 \mathrm{rpm}$ in a dark culture room. The suspension cells were subcultured in a fresh MS liquid medium supplemented with sucrose and 2,4-D every week.

\subsection{Plasmid Construction}

To make the $\alpha A m y 3$ promoter-signal peptide-Oct 4 fusion construct, the Gatewaycompatible binary T-DNA destination vector, pAAmy3Dst [21], was used. The 1083-bp Oct4 cDNA fragment was amplified by RT-PCR using the forward primer (5'-CACCATGGCGGGACACCTGGCTTC- $3^{\prime}$ ) and the reverse primer (5'-TCAGTTTGAATGCATGGG-3'). The fragment was inserted into the $\mathrm{pENTR} / \mathrm{SD} / \mathrm{D}-\mathrm{TOPO}$ vector (Invitrogen) to generate the construct pENTR-Oct4, and subcloned into the pAAmy3Dst vector by LR recombination to generate the final expression vector pAAmy3-Oct4.

\subsection{Rice Transformation}

Transformation of rice was performed as described previously with a slight modification [44]. The expression vector, pAAmy3-Oct4, carrying the $\alpha A m y 3$ promoter-signal peptide-Oct4 cassette was introduced into Agrobacterium tumefaciens strain EHA105 by electroporation. The single colony of transformed Agrobacterium was incubated on AB medium at $22{ }^{\circ} \mathrm{C}$ for five days. Then, embryogenic calli were incubated with the Agrobacterium for 20-25 min. The calli were then transferred to a co-cultivation agar medium and incubated at $22{ }^{\circ} \mathrm{C}$ in the dark for 5-7 days. The calli were rinsed 8-10 times with $250 \mathrm{mg} / \mathrm{L}$ cefotaxime in sterile distilled water, dried on sterile filter paper, transferred onto a selection medium that contained $50 \mathrm{mg} / \mathrm{L}$ hygromycin, and incubated at $28^{\circ} \mathrm{C}$. Transformed calli were regenerated on a regeneration medium supplemented with $50 \mathrm{mg} / \mathrm{L}$ hygromycin. 


\subsection{PCR-Base Genotype Analysis}

Genomic DNA was isolated from each rice cell line, either from calli or suspension cells. Two micrograms of genomic DNA were subjected to PCR using a specific primer set, Oct4-162F (5'-CTCTGAGGTGTGGGGGATT-3') and Oct4-419-R (5'-TTGATGTCCTGGGACTCCTC-3'), to amplify the Oct 4 gene. The PCR products were separated by electrophoresis. The primers Act1-F (5'-CTGATGGACAGGTTATCACC-3') and Act1-R (5'-CAGGTAGCAATAGGTATTACAG-3 $3^{\prime}$ ) were used for amplification of the internal reference gene Act1.

\subsection{Quantitative RT-PCR}

Total RNA was isolated from rice suspension cells using the TRIzol Reagent (SigmaAldrich, St Louis, MO, USA). Isolated total RNA was treated with RNase-free DNase I (NEB, Ipswich, MA, USA) to eliminate possible DNA contamination. First-strand cDNA was synthesized from $2.5 \mu \mathrm{g}$ total RNA using ReverTra Ace ${ }^{\circledR}$ reverse transcriptase (Toyobo, Osaka, Japan) with oligo-dT primers. A 10-fold dilution of the resultant first-strand cDNA was subjected to qRT-PCR using the Oct4-specific primers Oct4-162-F and Oct4419-R. The procedure was independently repeated at least three times. The relative gene expression was expressed as the ratio of Oct4 mRNA abundance to Act1 mRNA abundance. Data were analyzed using PikoReal 2.0 software (Thermo Fisher Scientific, Waltham, MA, USA).

\subsection{Western Blot Analysis}

Cells were collected from a sugar-free liquid medium after incubation at $28^{\circ} \mathrm{C}$ on an orbital shaker at $110 \mathrm{rpm}$ in a dark culture room. To isolate total secretory proteins from rice suspension cells, a cell-culture medium was filtered by $0.45 \mu \mathrm{m}$ to remove cell debris. To obtain the 10-fold-concentrated cell-culture medium protein, $500 \mu \mathrm{L}$ cell-culture medium was lyophilized in a FreeZone freeze dryer $\left(\right.$ Labconco $^{\mathrm{TM}}$, Kansas, MO, USA), and the dried pellet was dissolved in $50 \mu \mathrm{L} \mathrm{ddH2O}$. The concentration of protein in the supernatant was measured using a protein assay reagent (Bio-Rad, Hercules, CA, USA). Protein blot analysis was performed as described by Huang et al. [26] with an anti-human Oct4 monoclonal antibody (Merck, Darmstadt, Germany). Recombinant purified TAT-Oct4 protein from E. coli was used as a positive control. An ECL ${ }^{\text {TM }}$ Prime Western Blotting System was used following the manufacturer's recommended concentration to detect the protein signal with a Bio-Rad Gel Doc ${ }^{\mathrm{TM}}$ EZ imaging system.

\subsection{Oct4 Transcription Factor Binding Assay}

The Oct4 activity assay was conducted using TransAM ${ }^{\circledR}$ Oct-4 Transcription Factor Assay Kits, predominantly following the manufacturer's instructions. One gram of suspension cells was ground into fine powder in liquid nitrogen, and the fine powder was dissolved in $2 \mathrm{~mL}$ ice-cold lysis buffer as described in the protocol. The extracted protein sample was frozen immediately in liquid nitrogen and stored at $-80^{\circ} \mathrm{C}$. Twenty microliters of sample were transferred to each well on a 96-well plate, which had been immobilized with an oligonucleotide containing the Oct 4 consensus binding site (5'-ATTTGAAATGCAAAT- $3^{\prime}$ ). The P19 nuclear extract provided in the kits was used as a positive control.

\subsection{In-Gel Protease Activity Assay}

Proteinase activities analysis was performed as described by Lin et al. [42]. Rice suspension cells were cultured in a sugar-free medium for two days, a cell-culture medium was filtered by $0.45 \mu \mathrm{m}$ to remove cell debris. The culture medium was diluted 3-fold in a sample preparation buffer at $37^{\circ} \mathrm{C}$ for $10 \mathrm{~min}$, and then was subjected to SDS-PAGE containing $0.1 \%$ gelatin at $4{ }^{\circ} \mathrm{C}$ until the dye front reaches the bottom of the gel. The gels were then washed in $2.5 \%(\mathrm{w} / \mathrm{v})$ Triton X-100 for $30 \mathrm{~min}$, and incubated in potassium buffer ( $150 \mathrm{mM}$ potassium citrate, $5 \mathrm{mM} \mathrm{L-Cys,} 0.1 \%$ Triton $\mathrm{X}-100, \mathrm{pH} 5.8$ ) for $20 \mathrm{~h}\left(\right.$ at $37^{\circ} \mathrm{C}$ ). The gels were stained with Coomassie blue. 


\section{Conclusions}

In this study, we developed a platform to produce recombinant human Oct4 using the $\alpha A m y 3$ sugar starvation-inducible promoter and its signal peptide in a rice cell suspension culture system. The predicted $43 \mathrm{kDa}$ Oct 4 recombinant protein was detected among the intracellular soluble proteins and showed in vitro binding assay activity. The highest yield of Oct 4 was approximately $0.41 \%$ of total soluble proteins. Three small Oct 4 fragments were detected in the cell-culture medium, which implies that the secreted Oct4 proteins might be degraded by extracellular rice proteases. Therefore, future investigation of the correlation between recombinant human Oct4 protein and protease activities in the rice cell suspension culture system is recommended.

Supplementary Materials: These can be found at https:/ /www.mdpi.com/1422-0067/22/3/1409/s1. Author Contributions: Conceptualization and funding acquisition, L.-F.H. and C.-H.H.; project administration, supervision and original draft preparation, L.-F.H.; methodology and investigation, D.S.S., C.-C.T. and S.-J.M.H. All authors have read and agreed to the published version of the manuscript.

Funding: This work was supported by grants from the Ministry of Science and Technology of the Republic of China (106-2313-B-155-001-MY3).

Institutional Review Board Statement: Not applicable.

Informed Consent Statement: Not applicable.

Data Availability Statement: The data presented in this study are available on request from the corresponding author.

Acknowledgments: Yi-Ching Liu offered administration supports in this study.

Conflicts of Interest: Taiwan Advance Bio-Pharmaceutical Inc. had no role in the design of the study; in the collection, analyses, or interpretation of data; in the writing of the manuscript, or in the decision to publish the results.
Abbreviations
Oct4 Octamer-binding Transcription Factor 4
iPSCs induced pluripotent stem cells
qRT-PCR quantitative real-time PCR
MS medium Murashige and Skoog medium

\section{References}

1. Elitt, M.S.; Barbar, L.; Tesar, P.J. Drug screening for human genetic diseases using iPSC models. Hum. Mol. Genet. 2018, 27, 89-98. [CrossRef] [PubMed]

2. Kumar, S.; Blangero, J.; Curran, J.E. Induced pluripotent stem cells in disease modeling and gene identification. Methods Mol. Biol. 2018, 1706, 17-38. [PubMed]

3. Chun, Y.S.; Chaudhari, P.; Jang, Y.Y. Applications of patient-specific induced pluripotent stem cells; focused on disease modeling, drug screening and therapeutic potentials for liver disease. Int. J. Biol. Sci. 2010, 6, 796-805. [CrossRef]

4. Zaret, K.S.; Mango, S.E. Pioneer transcription factors, chromatin dynamics, and cell fate control. Curr. Opin. Genet. Dev. 2016, 37, 76-81. [CrossRef] [PubMed]

5. Schöler, H.R.; Hatzopoulos, A.K.; Balling, R.; Suzuki, N.; Gruss, P. A family of octamer-specific proteins present during mouse embryogenesis: Evidence for germline-specific expression of an Oct factor. EMBO J. 1989, 8, 2543-2550. [CrossRef] [PubMed]

6. Schöler, H.R.; Balling, R.; Hatzopoulos, A.K.; Suzuki, N.; Gruss, P. Octamer binding proteins confer transcriptional activity in early mouse embryogenesis. EMBO J. 1989, 8, 2551-2557. [CrossRef]

7. Takahashi, K.; Yamanaka, S. Induction of pluripotent stem cells from mouse embryonic and adult fibroblast cultures by defined factors. Cell 2006, 126, 663-676. [CrossRef]

8. Karwacki-Neisius, V.; Göke, J.; Osorno, R.; Halbritter, F.; Ng, J.H.; Weiße, A.Y.; Wong, F.C.; Gagliardi, A.; Mullin, N.P.; Festuccia, N.; et al. Reduced Oct4 expression directs a robust pluripotent state with distinct signaling activity and increased enhancer occupancy by Oct4 and Nanog. Cell Stem Cell. 2013, 12, 531-545. [CrossRef]

9. Niwa, H.; Miyazaki, J.; Smith, A.G. Quantitative expression of Oct-3/4 defines differentiation, dedifferentiation or self-renewal of ES cells. Nat. Genet. 2000, 24, 372-376. [CrossRef] 
10. Thier, M.; Münst, B.; Edenhofe, F. Exploring refined conditions for reprogramming cells by recombinant Oct4 protein. Int. J. Dev. Biol. 2010, 54, 1713-1721. [CrossRef]

11. Chou, B.K.; Mali, P.; Huang, X.; Ye, Z.; Dowey, S.N.; Resar, L.M.S.; Zou, C.; Zhang, Y.A.; Tong., J.; Cheng, L. Efficient human iPS cell deri- vation by a non-integrating plasmid from blood cells with unique epigenetic and gene expression signatures. Cell Res. 2011, 21, 518-529. [CrossRef] [PubMed]

12. Woltjen, K.; Michael, I.P.; Mohseni, P.; Desai, R.; Mileikovsky, M.; Hamalainen, R.; Cowling, R.; Wang, W.; Liu, P.; Gertsenstein, M.; et al. PiggyBac transposition reprograms fibroblasts to induced pluripotent stem cells. Nature 2009, 458, 766-770. [CrossRef] [PubMed]

13. Hou, P.; Li, Y.; Zhang, X.; Liu, C.; Guan, J.; Li, H.; Zhao, T.; Ye, J.; Yang, W.; Liu, K.; et al. Pluripotent stem cells induced from mouse somatic cells by small-molecule compounds. Science 2013, 341, 651-654. [CrossRef] [PubMed]

14. Cho, H.J.; Lee, C.S.; Kwon, Y.W.; Paek, J.S.; Lee, S.H.; Hur, J.; Lee, E.J.; Roh, T.Y.; Chu, I.S.; Leem, S.H.; et al. Induction of pluripotent stem cells from adult somatic cells by protein-based reprogramming without genetic manipulation. Blood 2010, 11, 386-395. [CrossRef]

15. Warren, L.; Manos, P.D.; Ahfeldt, T.; Loh, Y.H.; Li, H.; Lau, F.; Ebina, W.; Mandal, P.K.; Smith, Z.D.; Meissner, A.; et al. Highly efficient reprogramming to pluripo- tency and directed differentiation of human cells with synthetic modified mRNA. Cell Stem Cell 2010, 7, 618-630. [CrossRef]

16. Sterneckert, J.; Höing, S.; Schöler, H.R. Concise review: Oct4 and more: The reprogramming expressway. Stem Cells 2012, 30, 15-21. [CrossRef]

17. Zhang, H.; Ma, Y.; Gu, J.; Liao, B.; Li, J.; Wong, J.; Jin, Y. Reprogramming of somatic cells via TAT-mediated protein transduction of recombinant factors. Biomaterials 2012, 33, 5047-5055. [CrossRef]

18. Kim, D.; Kim, C.H.; Moon, J.I.; Chung, Y.G.; Chang, M.Y.; Han, B.S.; Ko, S.; Yang, E.; Cha, K.Y.; Lanza, R.; et al. Generation of human induced pluripotent stem cells by direct delivery of reprogramming proteins. Cell Stem Cell 2009, 4, 472-476. [CrossRef]

19. Pan, C.; Jia, W.; Lu, B.; Bishop, C.E. Expression of TAT recombinant Oct4, Sox2, Lin28, and Nanog proteins from baculovirusinfected Sf9 insect cells. Gene 2015, 556, 245-248. [CrossRef]

20. Wang, H.; Zhang, X.; Kong, N.; Wei, A.; Zhang, Y.; Ma, J.; Zhou, Y.; Yan, W. Expression, purification and characterization of a recombinant Tat47-57-Oct4 fusion protein in Pichia pastoris. Mol. Med. Rep. 2014, 9, 471-475. [CrossRef]

21. Liu, G.D.; Zhou, S.F.; Ding, X.C.; Fang, C.L.; Mi, S.Y.; Gao, X.C.; Han, Q. Soluble expression of recombinant cMyc, Klf4, Oct4, and Sox2 proteins in bacteria and transduction into living cells. Int. J. Ophthalmol. 2017, 10, 560-566. [PubMed]

22. Andrews, G.R.; Roberts, S.C. Bioprocess Engineering of Plant Cell Suspension Cultures. In Applied Bioengineering; Yoshida, T., Ed.; Wiley: New Jersey, NJ, USA, 2017; pp. 283-326.

23. Nishimura, A.; Aichi, I.; Matsuoka, M. A protocol for Agrobacterium-mediated transformation in rice. Nat. Protoc. 2006, 1, 2796-2802. [CrossRef] [PubMed]

24. Hiei, Y.; Ohta, S.; Komari, T.; Kumashiro, T. Efficient transformation of rice (Oryza sativa L.) mediated by Agrobacterium and sequence analysis of the boundaries of the T-DNA. Plant J. 1994, 6, 271-282. [CrossRef] [PubMed]

25. Kuo, Y.C.; Tan, C.C.; Ku, J.T.; Hsu, W.C.; Su, S.C.; Lu, C.A.; Huang, L.F. Improving pharmaceutical protein production in Oryza sativa. Int. J. Mol. Sci. 2013, 14, 8719-8739. [CrossRef]

26. Huang, L.F.; Liu, Y.K.; Lu, C.A.; Hsieh, S.L.; Yu, S.M. Production of human serum albumin by sugar starvation induced promoter and rice cell culture. Transgenic Res. 2005, 14, 569-581. [CrossRef]

27. Liu, Y.K.; Huang, L.F.; Ho, S.L.; Liao, C.Y.; Liu, H.Y.; Lai, Y.H.; Yu, S.M.; Lu, C.A. Production of mouse granulocyte-macrophage colony-stimulating factor by gateway technology and transgenic rice cell culture. Biotechnol. Bioeng. 2012, 109, 1239-1247. [CrossRef]

28. Kim, T.G.; Baek, M.Y.; Lee, E.K.; Kwon, T.H.; Yang, M.S. Expression of human growth hormone in transgenic rice cell suspension culture. Plant Cell Rep. 2008, 27, 885-891. [CrossRef]

29. Lee, J.H.; Kim, N.S.; Kwon, T.H.; Jang, Y.S.; Yang, M.S. Increased production of human granulocyte-macrophage colony stimulating factor (hGM-CSF) by the addition of stabilizing polymer in plant suspension cultures. J. Biotechnol. 2002, 96, 205-211. [CrossRef]

30. Kim, B.G.; Kim, S.H.; Kim, N.S.; Huy, N.X.; Choi, Y.S.; Lee, J.Y.; Jang, Y.S.; Yang, M.S.; Kim, T.G. Production of monoclonal antibody against FimA protein from Porphyromonas gingivalis in rice cell suspension culture. Plant Cell Tiss. Org. 2014, 118, 293-304. [CrossRef]

31. Van Giap, D.; Jung, J.W.; Kim, N.S. Production of functional recombinant cyclic citrullinated peptide monoclonal antibody in transgenic rice cell suspension culture. Transgenic Res. 2019, 28, 177-188. [CrossRef]

32. Sun, Q.Y.; Ding, L.W.; Lomonossoff, G.P.; Sun, Y.B.; Luo, M.; Li, C.Q.; Jiang, L.; Xu, Z.F. Improved expression and purification of recombinant human serum albumin from transgenic tobacco suspension culture. J. Biotechnol. 2011, 155, 164-172. [CrossRef] [PubMed]

33. Lu, C.A.; Lim, E.K.; Yu, S.M. Sugar response sequence in the promoter of a rice alpha-amylase gene serves as a transcriptional enhancer. J. Biol. Chem. 1998, 273, 10120-10131. [CrossRef] [PubMed]

34. Chen, M.H.; Liu, L.F.; Chen, Y.R.; Wu, H.K.; Yu, S.M. Expression of alpha-amylases, carbohydrate metabolism, and autophagy in cultured rice cells is coordinately regulated by sugar nutrient. Plant J. 1994, 6, 625-636. [CrossRef] [PubMed]

35. Shin, Y.J.; Hong, S.Y.; Kwon, T.H.; Jang, Y.S.; Yang, M.S. High level of expression of recombinant human granulocyte-macrophage colony stimulating factor in transgenic rice cell suspension culture. Biotechnol. Bioeng. 2003, 82, 778-783. [CrossRef] 
36. Jang, H.; Kim, T.W.; Yoon, S.; Choi, S.Y.; Kang, T.W.; Kim, S.Y.; Kwon, Y.W.; Cho, E.J.; Youn, H.D. O-GlcNAc regulates pluripotency and reprogramming by directly acting on core components of the pluripotency network. Cell Stem Cell 2012, 11, 62-74. [CrossRef]

37. De Muynck, B.; Navarre, C.; Nizet, Y.; Stadlmann, J.; Boutry, M. Different subcellular localization and glycosylation for a functional antibody expressed in Nicotiana tabacum plants and suspension cells. Transgenic Res. 2009, 18, 467-482. [CrossRef]

38. Sharp, J.M.; Doran, P.M. Characterization of monoclonal antibody fragments produced by plant cells. Biotechnol. Bioeng. 2001, 73, 338-346. [CrossRef]

39. Stevens, L.H.; Stoopen, G.M.; Elbers, I.J.; Molthoff, J.W.; Bakker, H.A.; Lommen, A.; Bosch, D.; Jordi, W. Effect of climate conditions and plant developmental stage on the stability of antibodies expressed in transgenic tobacco. Plant Physiol. 2000, 124, 173-182. [CrossRef]

40. Kim, N.S.; Kim, T.G.; Kim, O.H.; Ko, E.M.; Jang, Y.S.; Jung, E.S.; Kwon, T.H.; Yang, M.S. Improvement of recombinant hGM-CSF production by suppression of cysteine proteinase gene expression using RNA interference in a transgenic rice culture. Plant Mol. Biol. 2008, 68, 263-275. [CrossRef]

41. Kim, N.S.; Jang, S.H.; Yu, H.Y.; Chung, N.D.; Kwon, T.H.; Yang, M.S.; Kim, T.G. Amylase and cysteine proteinase gene knockdown in rice cells using RNA interference for enhancing production of recombinant proteins. Plant Cell Tiss. Org. 2013, 114, 97-107. [CrossRef]

42. Lin, M.T.; Lee, H.H.; Ho, S.L. Characterization of the Proteases Activities in Rice Suspension Cultured Cells and Medium during Sucrose Starvation. Crop. Environ. Bioinform. 2008, 5, 237-247.

43. Murashige, T.; Skoog, F. A revised medium for rapid growth and bioassays with tobacco tissue cultures. Physiol. Plant. 1962, 15, 473-497. [CrossRef]

44. Huang, L.F.; Tan, C.C.; Yeh, J.F.; Liu, H.Y.; Liu, Y.K.; Ho, S.L.; Lu, C.A. Efficient secretion of recombinant proteins from rice suspension-cultured cells modulated by the choice of signal peptide. PLoS ONE 2015, 10, e0140812. [CrossRef] [PubMed] 